\title{
Effect of different fertilizer types on Arsenic removal capacity of two fern species
}

\author{
Anh hưởng của các dạng phân bón khác nhau lên khả năng loại bỏ Asen của \\ hai loài dưong xỉ
}

Research article

Bui, Thi Kim Anh*

Institute of Environmental Technology, Vietnam Academy of Science and Technology, 18 Hoang Quoc Viet, Hanoi, Vietnam

\begin{abstract}
More and more attention has been paid to the research on phytoremediation and hyperaccumulators. Arsenic (As) uptake by hyperaccumulator plant species depends on many different environmental factors. Fertilizer is one of the most important factors because the plant growth needs nutrients. In this study, the pot experiments were conducted in 12 weeks to understand the effect of different fertilizer on As removal capacity of Pityrogramma calomelanos and Pteris vittata. The results showed that, Arsenic concentration in the frond is higher than that in the root of the fern. As removal efficiency of the ferns from the soil amended with both inorganic and organic fertilizer is highest. The ferns removed As content in soil up to 7.4 and $12.6 \mathrm{mg}$ As per kg DW soil, respectively. For the control experiments without adding fertilizers, As removal ability of the ferns from the soil is lowest that was only $2.1 \mathrm{mg}$ As per $\mathrm{kg}$ DW soil.
\end{abstract}

Trên thế giới đã và đang có nhiều nghiên cưu, ưng dụng phương pháp sủ dụng thưc vật để xủ lý ô nhiễm, đặc biệt là các loài thực vật siêu tích tụ kim loại nặng. Sụ tích lũy Asen (As) trong các loài thực vật siêu tích lũy phu thuộc vào rất nhiều yếu tố môi trường và dinh duõong khác nhau. Phân bón là một trong nhũng yếu tố quan trọng nhất vì sụ phát triển cây rất cần chất dinh duõ̃ng. Trong nghiên cúu này, các thí nghiệm được tiến hành trong 12 tuần để đánh giá về ảnh hương của các loại phân bón khác nhau đến khả năng xủ lý ô nhiếm As trong đất của dưong xỉ. Kết quả thu được cho thấy, nồng độ As tích lũy trong phần thân của dưong xỉ cao hơn rất nhiều so với phần rễ của cây. Hiệu quả loại bỏ As ra khỏi đất của dương xỉ trong các thí nghiệm bổ sung cả phân bón vô co và phân bón hứu co là cao nhất. Pityrogramma calomelanos và Pteris vittata có thể loại bỏ hàm luợng As trong $1 \mathrm{~kg}$ trọng luợng khô đất tuơng ứng lên đến 7,4 và 12,6 mg. Các công thức thí nghiệm đối chứng không bổ sung phân bón thì cho hiệu quả loại bỏ As ra khỏi đất là thấp nhất chỉ 2,1 mg As trên $1 \mathrm{~kg}$ trọng luọng khô đất.

Keywords: Arsenic, hyperaccumulator, fertilizer, Pteris vittata, Pityrogramma calomelanos

\section{Introduction}

Arsenic (As) contamination is a subject of great concern due to its carcinogenic nature and its adverse effects on ecosystems (Centeno et al., 2002). Arsenic is found associated with many types of mineral deposits. The exploitation of ore minerals induced pollution by arsenic in large soil areas nearby mining sites (Chen et al., 2006). High arsenic concentration in the soil near mining sites is a serious problem in many countries of the world (Kien et al., 2009; Kim Anh et al., 2011). Therefore, remediation of As-contaminated soils has become an important issue. Among the technologies established for the treatment of soils polluted with toxic elements, within the last years, phytoremediation techniques appeared as suitable ones to deal with polluted mine sites. Since these are costeffective methods with a minimum of negative environmental impacts (Baker et al., 2000).

There are many methods used for remediating heavy metal pollution but only phytoremediation is a environmental friendly, aesthetically pleasing approach andmost suitable for developing countries (Ghosh et al., 2005). More than 500 plant species of metal and metalloid hyperaccumulators have been reported in literature (Hemen Sarma, 2011). A plant is classified as a hyperaccumulator 
when it meets some criteria including: a) when the level of heavy metal in the shoot divided by level of heavy metal in the root is greater than 1 (shoot/root quotient $>$ 1 ); b) when the level of heavy metal in the shoot divided by total level of heavy metal in the soil is greater than 1 (extraction coefficient $>1$ ) (Rotkitti-khun et al., 2006) and c) when the plant can take up between $10-500$ times more heavy metals than normal plants can (uncontaminated plants - control plants) (Fifield and Haines 2000).

Not much research has focused on Arsenic hyperaccumulation by terrestrial plants. The first known As hyperaccumulator was Pteris vittata (Ma et al., 2001). Since then, several other fern species such as Pityrogramma calomelanos (Visoottiviseth et al., 2002), Pteris longifolia, Pteris umbrosa, Pteris cretica (Zhao et al., 2002), Pteris multifida (Du et al., 2005), Pteris biaurita, Pteris quadriaurita and Pteris ryukyuensis (Srivastava et al., 2006) were reported as As hyperaccumulators in the world. There are two As hyperaccumulator ferns that were discovered from a survey of vegetation of As-contaminated land are Pteris vittata and Pityrogramma calomelanos (Chen et al., 2005; Tu et al., 2003; Ma et al., 2001; Francesconi et al., 2002). They were accumulated very high As concentration in the frond and very popular in mining areas of Vietnam (Kim Anh et al., 2011).

The As uptake by plant species depends on environmental factors, such as soil type, nutrient supply, clay and iron oxides, microorganisms and medium $\mathrm{pH}$ (Khan, 2005). Among all the factors, nutrient supply is one of the most important influencing to plant growth and As uptake because of its growing depend on nutrient applying The important is how to improve the efficiency of phytoremediation by increasing the key factor that enhances plant As uptake. So, the objectives of this study were: (1) to assess the effect of different fertilizer types on plant biomass production of Pteris vittata and Pityrogramma calomelanos, (2) to find the fertilizer application by suitable way for enhancing As remediation in the soil by the ferns.

\section{Materials and methods}

\subsection{Soil collection and characterization}

The soil samples used in the greenhouse experiment were collected from the surface soil layer $(0-20 \mathrm{~cm})$ at the experimental biology farm in the Tu Liem district, Hanoi, Vietnam. The physicochemical properties of the soil were as follows: the soil had relatively loams texture, $\mathrm{pH}(\mathrm{KCl})$ 7.8 , organic matter content $5.3 \%$, total N 640 mg. $\mathrm{kg}^{-1}$, total P 435.7 mg.kg ${ }^{-1}$, cation exchange capacity (CEC) 9.2 cmol. $\mathrm{kg}^{-1}$, total As 24.9 mg. $\mathrm{kg}^{-1}$.

\subsection{Plant growth conditions}

Spores of Pteris vittata and Pityrogramma calomelanos were collected from mining areas in Thai Nguyen province ( $\mathrm{Zn}-\mathrm{Pb}$ mining in Dong Hy distric and Ti-Sn mining in i Tu distric). Seedlings were sown from spores in sterilized mixture of potting soil (35\%), peat moss (30\%) and fine quartz sand $(30 \%)$, and lime $(5 \%)$. Seedlings were transplanted into sterilized vermiculite. After sowing, the vermiculite was kept moist by watering spray everyday. At the age of six months, the seedlings were used to set up experiments.

\subsection{Experimental design}

Mature Pteris vittata and Pityrogramma calomelanos plants (ca. 6 months old), with five to six fronds, growing in large plastic pots were used for this study. There were five treatments sets with five replicates for each. Each plastic pot contained $1 \mathrm{~kg}$ of the normal soil, growing one fern, As concentration was $300 \mathrm{mg} \cdot \mathrm{kg}^{-1}$ by adding $\mathrm{Na}_{2} \mathrm{HAsO}_{4} \cdot 7 \mathrm{H}_{2} \mathrm{O}$ solution to the soil sample. Two types of fertilizers are widely used in the Vietnam market was taken into the experiment. They are organic fertilizers Song Gianh (Components of this fertilizer: $\mathrm{P}_{2} \mathrm{O}_{5}: 1.5 \%$, Ca: 0,1\%; Mg: 0,5\%; S:0.2 \%; Aspergilus sp.: $10^{6}$ CFU/g; Azotobacter: $10^{6} \mathrm{CFU} / \mathrm{g}$; Bacillus: $10^{6} \mathrm{CFU} / \mathrm{g}$ ) and inorganic fertilizer NPK (N: 25\%; $\mathrm{P}_{2} \mathrm{O}_{5}: 25 \% ; \mathrm{K}_{2} \mathrm{O}: 5$ $\%$ with other secondary and micro-nutrients elements). The control is without fertilizer application. Four sets with different manuring of CT1 (0.8 g Song Gianh), CT2 (0.8 g NPK), CT3 (0.2 g NPK and $0.4 \mathrm{~g}$ Song Gianh) and CT4 (0.1 g NPK and 0.6 g Song Gianh) were established in each pot. Twelve weeks after the application of fertilizers, the greenhouse experimental plants were harvested and then separated into frond and root biomass. One sample from the soil, frond and root of every replication from each treatment was put into plastic bags and immediately brought to the laboratory to prepare for analysis.

\subsection{Soil and plant analysis}

Soil samples (approximately 150-200 g soil of each plastic pot) were air dried, crushed down to pass through a sieve have $1 \mathrm{~mm}$ size and stored at $4^{\circ} \mathrm{C}$ in dark plastic bags until being analysed. The plant samples were washed with tap water to remove soils and dust, rinsed with deionized water, and oven dried at $60^{\circ} \mathrm{C}$ for 4 days. Digestion of heavy metals was conducted by using US EPA 3051 method. Concentrations of total As in acid digests were quantified with an atomic absorption spectroscopy (AAS; AA-6800, Shimadzu, Japan) and on inductively coupled plasma-mass spectroscopy (ICP-MS, ELAN 9000, Perkin Elmer, USA). Physicochemical properties of the soil were determined according to Ryan et al. (2001). 


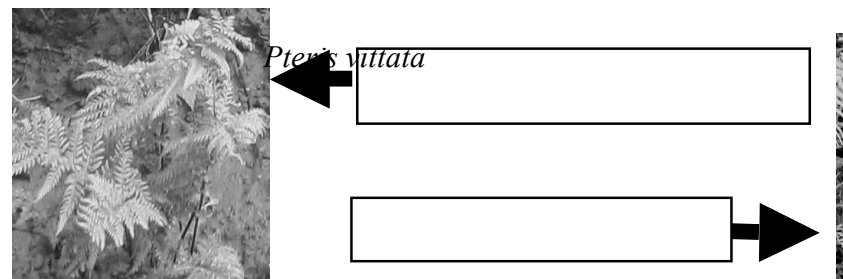

Figure 1. Two fern species were used for the experiment

Reagent blanks and reference material standard from Canadian National Research Council (NRC) (TORT-2) were used to verify the precision of the digestion procedure and the subsequent analysis.

All the data in the mean and standard deviation calculations were performed using Microsoft Excel from the windows operating system. Comparison of treatment means were made using one-way ANOVA R. Results were considered significant at the $P \leq 0.05$ level.

\section{Results and discussion}

\subsection{Arsenic Distribution in the fern}

Arsenic concentrations in frond and root of the ferns were different depending on each fertilizer application (Figure 2). For the Pteris vittata, they were $1020.1 \pm 44.6,1359.8$ $\pm 111.8,1521.3 \pm 88,2730.2 \pm 91.1$ and $2271.2 \pm$ $96.9 \mathrm{mgkg}^{-1}$, respectively in the plant frond at control, CT1, CT2, CT3 and CT4, and were $345 \pm 28.3,420.9 \pm$ $18.8,891.2 \pm 30.4,1053.1 \pm 57.6$ and $647.4 \pm 29.3 \mathrm{mgkg}^{-}$ ${ }^{1}$, respectively in the plant root at control, CT1, CT2, CT3 and CT4. For the Pityrogramma calomelanos, they were $1105.3 \pm 100.9,1245.5 \pm 69.5,1237.3 \pm 110.4,2120.3 \pm$ 105.4 and $2010.2 \pm 59.4 \mathrm{mgkg}^{-1}$, respectively in the plant frond at control, CT1, CT2, CT3 and CT4 and were 295.6 $\pm 52,320.9 \pm 19.5,545.2 \pm 38,953.2 \pm 22.1$ and $567.4 \pm$

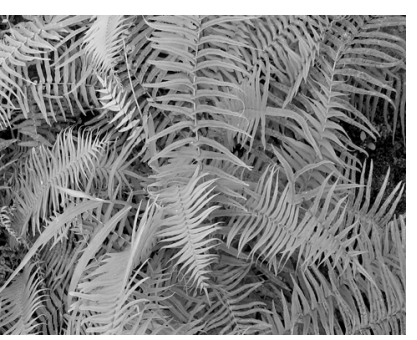

$32.8 \mathrm{mgkg}^{-1}$, respectively in the plant root at control, CT1, CT2, CT3 and CT4. The As concentrations in the frond of Pteris vittata and Pityrogramma calomelanos at CT3 were higher than the ones at CT4 1.2 and 1.05 times, and in the root these values were 1.62 and 1.7 times, respectively. Among all the treatments, the ferns growing in CT3 (added $0.2 \mathrm{~g} \mathrm{NPK}$ and $0.4 \mathrm{~g}$ Song Gianh per kg soil) had the highest arsenic concentration, while the control had the lowest. As concentration in the ferns of CT4 was smaller than that of CT3 but higher than the other formulas. So, the ability to accumulate As was the best in the treatments added mix organic and inorganic fertilizer, followed by the treatment added only inorganic fertilizer and finally is the treatment added only organic fertilizer.

As concentrations in the fronds and roots have a clear correlation at different fertilizer application. The As concentrations in the aboveground biomass were much greater than that in the roots. This finding is similar to the results of Chen. 2006 reporting that Chinese Brake fern (Pteris vittata) has taken up As mainly in the frond biomass. Arsenic accumulation by the plants is affected by arsenic concentration in soils, the soil's physical and chemical properties and the presence of other ions (Fitz and Wenzel, 2002). The results suggest that arsenic accumulation by two ferns was influenced by difference fertilizer types.

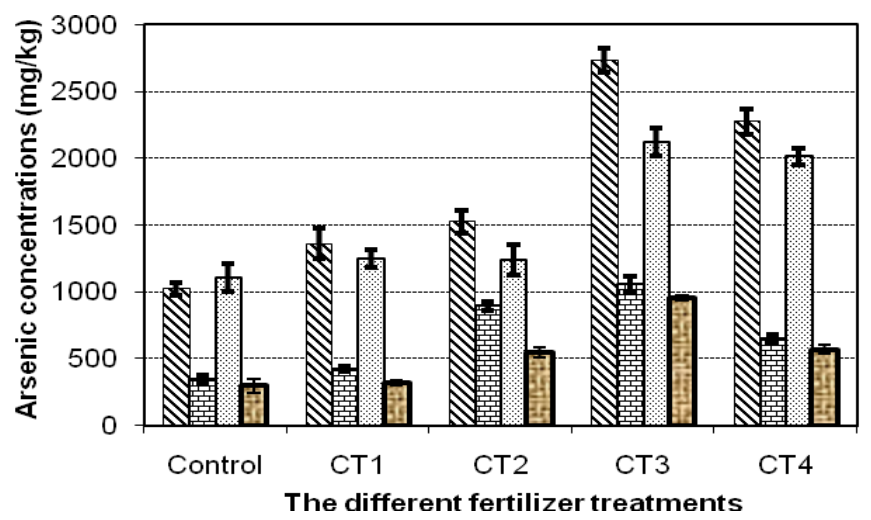

$\mathbf{\Delta}$ Pteris vittata frond

B Pteris vittata root

웅 Pityrogramma calomelanos

frond

- Pityrogramma calomelanos

root

Figure 2. Effect of different fertilizer types on As uptake by Pteris vittata and Pityrogramma calomelanos

\subsection{Effect of fertilizer on biomass production}

Results from the dry biomass of plants are summarized in Figure3. The effects of different fertilizer types on the plant biomass, after 12 weeks of growth in the greenhouse experiment, were significant. To evaluate the potential of two ferns for phytoextraction purposes, its frond biomass is the significant factor. Among all the treatments, the growth and aboveground biomass of the ferns were significantly enhanced in CT3, with the frond dry biomass of Pteris vittata and Pityrogramma calomelanos was $4.6 \pm$ 0.5 and $3.5 \pm 0.5$ g per plant, respectively (Figure 3 ). 


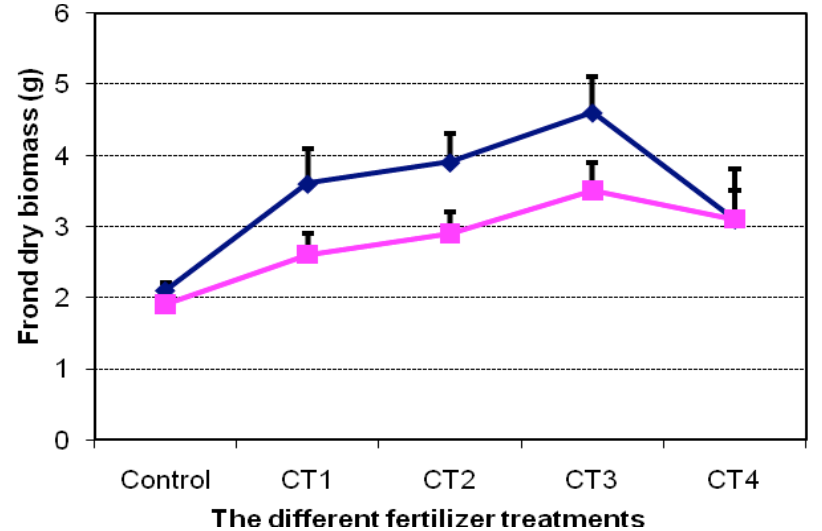

Figure 3. Effect of different fertilizer types on frond dry biomass of Pteris vittata and Pityrogramma calomelanos

In the CT1, CT2 and CT4 of two ferns, the frond biomass was less, compared to the CT3, but it was still slightly higher than that in the control. The dry biomass of root responded similarly to the frond. The plant biomass of Pteris vittata at CT1, CT2 and CT4 was higher than that at the control in the order of 1.7, 1.9 and 1.5 times, respectively. The plant biomass of Pityrogramma calomelanos at CT1, CT2 and CT4 was higher than that at the control in the order of $1.4,1.5$ and 1.6 times, respectively. The results suggested that optimum plant growth (dry biomass) could be achieved by adjusting fertilizer application with appropriate dose consisting of $0.2 \mathrm{~g}$ NPK and $0.4 \mathrm{~g}$ Song Gianh per $\mathrm{kg}$ soil. The dry biomass is one of two important factors that enhance As extract capacity from soil, when applying the fern for remediation. The second important factor is the concentration of As accumulated in the plant biomass.

\subsection{Arsenic translocation from roots to fronds}

The highest concentrations of As in Pteris vittata and Pityrogramma calomelanos were recorded at CT3 for plant fronds and roots. The ratio of As concentrations in fronds to in roots (TF) of two ferns found in different treatments varied between 1.7 and 3.9, depending on the fertilizer application (Table 1). The high arsenic accumulation in the fronds, combined with $\mathrm{TF}>1$ in all the treatments suggest that this fern can actively uptake As from soil and preferably store it in its aboveground parts. This indicates feasibility of the plant utilization for effective As-remediation in mining areas. These results agree with the reports of Chao Yang Wei and Tong Bin Chen published on Pteris vittata. The ability of two ferns to effectively translocate large amounts of arsenic to its fronds has been recognized as one of the mechanisms for its arsenic detoxification (Ma et al., 2001). With the research results on TF, two ferns consistently demonstrate a hyperaccumulation feature to arsenic in the mining field.

Application of the native plants species for phytoextraction is favoured as it requires less management and successfully acclimatization to climate conditions and seasonal cycles. Practice has demonstrated that organic fertilizer was applied in long-term to balance nutrition and enhance the natural fertility of the soil but it can't fully replace inorganic fertilizer. Therefore, to ensure the sustainable farming should combined harmoniously inorganic and organic fertilizer. Many models incorporating both of them bring high economic efficiency and minimize negative impact to the environment. The obtained results indicated that the efficiency of remediation of arseniccontaminated soils by the ferns can be increased by adding organic and inorganic fertilizer are 0.2 and $0.4 \mathrm{~g}$ per $\mathrm{kg}$ soil, respectively.

Table 1. Translocation factor of two ferns at different treatments

\begin{tabular}{ccccc}
\hline $\begin{array}{c}\text { Fertilizer treat- } \\
\text { ments }\end{array}$ & $\begin{array}{c}\text { TF*of Pteris } \\
\text { vittata }\end{array}$ & $\begin{array}{c}\text { TF of Pityrogramma } \\
\text { calomelanos }\end{array}$ & $\begin{array}{c}\text { As uptake by Pteris vit- } \\
\text { tata (mg As per each } \\
\text { plant frond**) }\end{array}$ & $\begin{array}{c}\text { As uptake by Pityrogramma } \\
\text { calomelanos (mg As per each } \\
\text { plant frond**) }\end{array}$ \\
\hline Control & 2.9 & 3.7 & 2.1 & 1.9 \\
CT1 & 3.2 & 3.9 & 4.9 & 3.2 \\
CT2 & 1.7 & 2.3 & 5.9 & 3.6 \\
CT3 & 2.6 & 2.2 & 12.6 & 7.4 \\
CT4 & 3.5 & 3.5 & 7.04 & 6.2 \\
\hline
\end{tabular}

*Transfer factor $=$ ratio of As concentrations in fronds to in roots. The values are mean \pm standard deviation of 5 replicates. $\quad * * \mathrm{mg}$ As per each plant frond = frond dry biomass $(\mathrm{g}) \times$ frond As $\left(\mathrm{mgkg}^{-1}\right) \times 10^{-3}$

\section{Conclusion}

Two ferns species can best growing and highest accumulation of Arsenic at the formula applied both inorganic and organic fertilizers. In the treatments added only inorganic or only organic fertilizer, As removal efficiency of the ferns is not high. The As removal ability from the soil of the ferns in the control (without fertilizer application) is lowest. As removal efficiency from the soil of two ferns in CT3 are highest. The frond of Pteris vittata and Pityrogramma calomelanos removed As content in soil up to 12.6 and $7.4 \mathrm{mg}$ per $\mathrm{kg}$ DW soil, respectively. 


\section{Acknowledgments}

This research was funded by the Vietnam National Foundation for Science \& Technology Development (NAFOSTED).

\section{References}

[1] Baker A. J. M, S. P. McGrath, R. D. H. Reeves.2000. Phytoremediation of contaminated soils and water. CRC - USA: 85-107.

[2] Bui Thi Kim Anh, Dang Dinh Kim, Tran Van Tua, Nguyen Trung Kien, Do Tuan Anh. 2011. Phytoremediation potential of indigenous plants from Thai Nguyen province, Vietnam. Journal of Environmental Biology 32: 257-262.

[3] Bui Thi Kim Anh, Dang Dinh Kim, P. Kuschk, T. V. Tua, N.T. Hue, N.N. Minh. 2013. Effect of soil $\mathrm{pH}$ on arsenic hyperaccumulation capacity in Pityrogramma calomelanos L.", Journal of Environmental Biology 34: 237-242.

[4] Centeno, J. A., Mullick, F. G., Martinez, L., Page, N. P., Gibb, H., Longfellow, D., Thompson, C., Ladich, E. R.2002. Pathology related to chronic arsenic exposure. Environ. Health Prospect 110: 883886.

[5] Cong Tu and Lena Q. Ma. 2001. Effects of Arsenic Concentrations and Forms on Arsenic Uptake by the Hyperaccumulator Ladder Brake. Journal of Environmental Quality 31: 641-647.

[6] Chen Tong-Bin, Chao- Yang Wei. 2006. Arsenic accumulation by two brake fern growing on an Arsenic mine and their potential in phytoremediation, Chemosphere 63: 1048-1053.

[7] Du W, Li Z, Zou B, Peng S. 2005. Pteris multifida Poir., a new arsenic hyperaccumulator: characteristics and potential. Int J Environ Pollut 23:388-396

[8] Francesconi, P. Visoottiviseth, W. Sridokchan, W. Goessler. 2002. Arsenic species in an arsenic hyperaccumulating fern, Pityrogramma calomelanos: a potential phytoremediator of arsnic-contaminated soils. Sci. Total Environ. 284: 27-35.
[9] F.J. Zhao, S.J. Dunham, S.P. McGrath.2002. Arsenic hyperaccumulation by different fern species. New Phytol. 156: 27-31.

[10] Fifield, F. W \& Haines, P.J. 2000. Environmental Analytical Chemistry. Wiley-Black well. 512.

[11] Fitz, W.J. and W.W. Wenzel. 2002. Arsenic transformations in the soil-rhizosphere-plant system: fundamentals and potential application to phytoremediation. Jounal of Biotechnology 99: 259-278

[12] Ghosh, S.P. SingH: A review on Phytoremediation of heavy metals and utilization of its byproduct. 2005. Applied Ecology and Environmental Research 3 (1): 1-18.

[13] Hemen Sarma. 2011. Metal Hyperaccumulation in plants: A review focusing on phytoremediation technology. J. Environ.Sci. Technol., 4 (2): 118-138.

[14] Kien Chu Ngoc, Noi Van Nguyen, Bang Nguyen Dinh, Son Le Thanh, Sota Tanaka, Yumei Kang, Katsutoshi Sakurai and Kozo Iwasaki.2009. Arsennic and heavy metal concentrations in the Agricultural soils around tin and tungsten mines in the Dai Tu district, N. Vietnam. Water air soil pollut 197:7589.

[15] P. Visoottiviseth, K. Francesconi, W. Sridokchan.2002. The potential of Thai indigeous plant species for the phytormediation of arsenic contaminated land. Environ. Pollut. 118: 453-461.

[16] Rotkittikhun, P, Kruatrachue, M, Chaiyarat, R, Ngernsansaruay, C, Pokethitiyook, P, Paijitprapaporn, A, \& Baker, A. J. M. 2006. Uptake and accumulation of lead by plants from the Bo Ngam lead mine area in Thailand. Environmental Pollution, 144: 681-688.

[17] Srivastava M, Ma LQ, Gonzaga Santos JA.2006. Three new arsenic hyperaccumulating ferns. Sci Total Environ, 364:24-31.

[18] Tu, C., Ma, L.Q. 2003. Effects of arsenate and phosphate on their accumulation by an arsenichyperaccumulator Pteris vittata L. Plant Soil, 249: 373-382. 